\title{
THE EFFECTIVENESS OF USING WORD WALL IN TEACHING SIMPLE PRESENT TENSE AT THE FIRST YEAR STUDENTS OF JUNIOR HIGH SCHOOL 1 PARIGI
}

\author{
Rahmat Syam \\ English Education Department of UIN Alauddin Makassar \\ rahmatsyam15@gmail.com
}

\begin{abstract}
This research is about the effectiveness of using word wall in teaching simple present tense at the first year students of Junior High School 1 Parigi. The study tried to answer this problem: "Is the word wall effective to be used in teaching simple present tense?". The objective of the research was to find out the effectiveness of word wall in teaching simple present tense at the first year students of Junior High School 1 Parigi. This research used quasi-experimental design. The population of this research was the first grade students of Junior High School 1 Parigi in academic year 2014/2015. The total number of the population was 48 students. The sample of the research was selected by using total sampling technique. They were divided into two classes, one of the two classes was experimental class and the other became the controlled class. The data were collected through test. After the treatment, the students' achievement from the pre-test to the post test has improved highly. It can be seen that, the improvement of their score from the pre-test till the post test. The mean score of the pre-test for the controlled class is $\mathbf{4 2 . 5 0}$, but it has increased to $\mathbf{6 8 . 9 5}$ at the post test. The mean score of the pre-test for the experimental class is 48.33 , but it has increased to $\mathbf{8 0 . 2 0}$ at the post test. It means that, the experimental class better than the controlled class. World wall has some advantages for the learning process, such as the colorful design of the word wall which could activate the student's thinking process and students will not be bored and passive in class because they will interact with the word wall. Based on the data above, the researcher concludes that word wall is effective to be used in teaching simple present tense. English teachers should explore more methods that could be used to teach simple present tense.
\end{abstract}

KEY WORDS: word wall, simple present, junior high school.

\section{A. INTRODUCTION}

$\mathbf{I}$ $\mathrm{n}$ the learning process, there are many problems faced by student in learning simple present tense. Based on the researcher's experience when he was studied at Junior high school, learning simple present tense was confusing.

The researcher did not know when to put $-\mathrm{s}$ or $-\mathrm{es}$ in making sentences. 
Rahmat Syam, The Effectiveness of Using Word Wall In Teaching Simple Present Tense ...

In addition, based on the result of observation from an English teacher at SMPN 1 Parigi May 2014, there are three difficulties faced by the students in mastering simple present tense. They are: First, most of students still do not understand the correct form and usage of simple present tense. Second, the students often make some mistakes in put the right verb in the sentences of the simple present tense. Third, they were not enthusiastic with the teaching and learning process about grammar.

These problems can be influenced by some factors. The writer assumed these problems are caused by method or technique in teaching grammar, since some teachers taught grammar just by giving explanation and exercises. Of course it makes students less understanding. It makes students less interested in grammar, and makes students bored. These problems are important to be solved so that students get more comprehension in material of grammar especially simple present tense, and students think that grammar is an interesting sub skill.

In order to solve these problems, we need to use other technique which is effective and more interesting in teaching grammar especially simple present tense. One of the techniques which could be used in teaching simple present tense is by using word wall.

Brummitt (2012) stated that to help students categorize their vocabularies and understand basic concepts of grammar, teachers can create a word wall organized by part of speech (ie. nouns, verbs, adjectives, adverbs).

Based on the explanations above, the researcher would like to conduct a research entitled: The Effectiveness of Using Word Wall in Teaching Simple Present Tense at the First Year of Junior High School 1 Parigi.

Furthermore, the research problem of this research was "is the word wall effective to be used in teaching simple present tense?". Then, the research objective was to find out whether the word wall is effective to be used in teaching simple present tense. In addition, this research was beneficial practically in the context for the students (they can improve their understanding on simple present tense), the teachers (they can implement a good alternative or technique in teaching grammar), and the further researcher (they can use the finding of this study as one of their references). Finally, this study was focused on finding out the effectiveness of using word wall in teaching simple present tense at the first year of junior high school. In this case, the use of word wall is not focused on building student's vocabulary, but it focuses on how to make the correct forms of simple present tense. Students used the words listed on the word wall to produce a sentence which has the correct form of simple present tense. 


\section{B. LITERATURE REVIEW}

A number of studies had been conducted in order to investigate the effectiveness of word wall in teaching English. First, Astuti (2010) in her research The Use of Word Wall as Media to Improve Students' Speaking Ability, an Action Research at the First Year Students of SMPN 1 Temanggung in the Academic Year of 2009/2010 found that the result of the study showed the improvement of the students' speaking skill after being taught by Word Wall media. It can be suggested as an alternative media to be implemented in the teaching learning process.

The other research from Maria Marshinta Aritonang (2010) academic year student of State University of Medan had done a research by using word walls in vocabulary. She conducted an action research; It focused on improving students' achievement on vocabulary through word walls. Word walls is an effective, enjoyable, and interesting way to each vocabulary because it can help the students to recognize, promote independence, develop a growing core of words, and provide reference support for students during their reading and writing.

Furthermore, Anggriani (2013) in her research Improving Students' Vocabulary Achievement through Word Walls Strategy found that the finding of this research is that Word Walls strategy can help the students improve their vocabulary achievement. By applying this Word Walls strategy, the score of the students in vocabulary kept increasing from the orientation-test until the post-test of cycle 2. It was proved by the data which showed that the mean of the students in the post-test II (79.04) was higher than that of the post-test I (63.68) and also higher than that of pre-test (48.48).

It can be concluded that word wall group is effective to improve the students' English ability. The researcher tried to apply the word wall in teaching simple present.

\section{Word wall}

This section presented the function of word wall in teaching.

\section{a. Word wall}

A word wall is an ongoing, organized display of key words that provides visual reference for students throughout a unit of study or a term. These words are used continually by teachers and students during a variety of activities (Indrayana, 2014). Therefore, Word walls support student's ongoing study of how words work and should be interactive, not simply a display of words. Word walls encourage students to actively learn about words and therefore should be referenced and used often mastering simple present. Word wall is a collection of high-frequency sight 
words that are age appropriate, classified into groups or categories, and is located on the wall of a classroom for students to easily see and learn.

\section{b. Advantages of Word wall in Teaching Simple Present}

The word wall support students' vocabulary development as students a consciously turn to their word wall in their break time and while there are in the classroom. The second is it provides reference support for students during the English classes for the whole semester. The third is word wall teaches students to remember and spell words, see patterns and relationship in words. The forth is by using word wall, the word will be settled in students' long term memory allowing quick and easy access. And the last one is it can be use as class décor. So the word wall game is very supportive to the students in mastering simple present tense, many teacher believed that the word wall really works for their students, similar researcher on the use of word wall game has not yet been carried out in the local setting. This fact, inspired the researcher to conduct this study on word wall. Therefore, the researcher intends to teach simple present tense using the word wall.

\section{RESEARCH METHOD}

The researcher conducted a quasi-experimental design to find out the effectiveness of using word wall in teaching simple present tense. The procedure of the quasi-experimental research used in this study was presented as the following.

$\begin{array}{cccc}\text { Group } & \text { Pre-Test } & \text { Treatment } & \text { Post-Test } \\ \text { E } & 0_{1} & \mathrm{X} & 0_{2} \\ \text { C } & 0_{1} & - & 0_{2}\end{array}$

Figure 1. Quasi-Experimental

This research was the fourth semester students offering of class VII A \& B at the first grade of Junior High School 1 Parigi in academic year of 2013/2014 for three months started from September TO December. Class A consists of 24 students and class B consists of 24 students. Class A was an experimental class, and then class $\mathrm{B}$ was a controlled class. In other words, the first year students of High School 1 Parigi consisting of 48 students involved as sample of this research.

To obtain valid data, the researcher used test as the instrument. It was divided into three parts. The first was multiple choices consisting of 10 items. The second was filling in the blank consisting 5 items. The last was changing sentence consisting 5 items. The content of the test given in the pre-test and post-test were the same content but they were different forms. The test specification can be seen in Table 1: 
Table.1. Test Specification

\begin{tabular}{|l|l|l|l|l|l|}
\hline \multirow{2}{*}{ No } & \multirow{2}{*}{$\begin{array}{c}\text { Materials of Simple } \\
\text { Present Tense }\end{array}$} & \multicolumn{1}{|c|}{$\begin{array}{c}\text { Multiple } \\
\text { Choice }\end{array}$} & $\begin{array}{c}\text { Fill In The } \\
\text { Blank }\end{array}$ & $\begin{array}{c}\text { Changing } \\
\text { Sentence }\end{array}$ & Total \\
\cline { 3 - 6 } & \multicolumn{1}{|c|}{$\begin{array}{l}\text { The use of V1 } \\
2\end{array}$} & $\begin{array}{l}\text { The use of auxiliary } \\
\text { Tam, is, are) }\end{array}$ & $5,7,4,6,10$, & 11,15 & 7 \\
3 & Time signal & 3,9 & $12,13,14$ & & 6 \\
4 & Changing Sentence & & & & 2 \\
\hline
\end{tabular}

There were ten meetings that the researcher needed to collect valid data. Each meeting consisted of 70 minutes. To make it clear, it was explained in the following chronological:

\section{Pre test}

In the first meeting, the students were given a pre-test. Students were asked to answer some questions dealing with simple present tense. The test consisted of three parts: 10 items multiple choices, 5 items of Fill in the Blank and 5 items for Changing Sentence (see Table 1). They were given 45 minutes to finish the test.

\section{Treatment}

In the second to the ninth meetings the researcher gave treatments for the students. The treatment was conducted as follow:

In the second to the third meetings, he started this session by introducing and explaining about simple present tense to the students. After that, he gave examples of simple present tense informs of positive, negative and interrogative sentence.

In the fourth meeting, the researcher introduced word wall to the students. He used the word wall as a media to arrange sentences that have a form of simple present tense. After that, he asked the students to list the sentences they had found after using the word wall. Then, the researcher divided the students into four groups and asked each group to make a word wall as their home work.

In the fifth and sixth meeting, each group presented their word wall in front of the class and asked other groups to make sentences using that word wall. In the seventh to ninth meetings, the researcher started learning process by asking the students to remain what the simple present tense is. Then, he asked the students to make sentences in forms of positive, negative, and interrogative sentence. 
Rahmat Syam, The Effectiveness of Using Word Wall In Teacbing Simple Present Tense ...

\section{Post Test}

In the last meeting, the researcher gave a post-test to the students in order to find out the students' achievements and progress in mastering simple present tense. The test given had same content but different forms.

The data gained from pre-test and post-test were analyzed by using descriptive analysis with statistical calculation. The following is the procedure:

The scoring classification can be seen in Table 2:

Table.2.Scoring Classification

\begin{tabular}{|c|c|c|}
\hline No & Formed & Score \\
\hline \multirow[t]{2}{*}{1.} & Multiple Choices & For right answer, each item is given score 1 \\
\hline & & For wrong answer, each item is given score 0 \\
\hline \multirow[t]{2}{*}{2.} & Fill in the Blank & For right answer, each item is given score 1 \\
\hline & & For wrong answer, each item is given score 0 \\
\hline \multirow[t]{2}{*}{3.} & Changing Sentence & For right answer, each item is given score 1 \\
\hline & & For wrong answer, each item is given score 0 \\
\hline
\end{tabular}

To score pre-test and post-test by using the following formula

Score: $\quad \frac{\text { the students'gained score }}{\text { total score }} \times 100$

(Sudjana, 2008)

To classify the students' score answer into the following criteria

Table.3. Scoring Rank

\begin{tabular}{|l|l|c|}
\hline No & Classification & Range of Score \\
\hline 1. & Excellent & $96-100$ \\
2. & very good & $86-95$ \\
3. & Good & $76-85$ \\
4. & Fairly good & $66-75$ \\
5. & Fair & $56-65$ \\
6. & poor & $46-55$ \\
7. & Very Poor & $0-45$ \\
\hline
\end{tabular}

To find out the mean score, by the following formula:

$$
X=\frac{\sum x}{N}
$$

Where:

$X:$ Mean score 


$$
\begin{array}{ll}
\sum x & : \text { The sum of all scores } \\
N & : \text { The number of students }
\end{array}
$$

a. Finding out standard deviation of the students' score in pre-test and post-test by Where: using the following formula:

$$
S D=\frac{\sqrt{\sum x^{2}-\frac{\left(\sum x\right)^{2}}{N}}}{N-1}
$$

b. $S D$ : Standard deviation

$$
\begin{array}{ll}
\sum_{N} x x^{2} & : \text { The sum of all score } \\
N & \text { : The sum square of all sore } \\
\text { Total number of students }
\end{array}
$$

The research used $\mathrm{T}_{\text {test }}$ to know whether there is a significant difference between the two groups before and after the treatment, $\mathrm{T}$ test including as follow:

$$
t=\frac{\overline{\mathrm{x}} 1-\overline{\mathrm{x}} 2}{\sqrt{\left(\frac{\mathrm{SS} 1+\mathrm{SS} 2}{\mathrm{n} 1+\mathrm{n} 2-2)\left(\frac{1}{\mathrm{n} 1}+\frac{1}{\mathrm{n} 2}\right)}\right.}}
$$

Where:

$$
\begin{aligned}
& \mathrm{SS} 1=\sum \mathrm{X} 1^{2}-\frac{\left(\sum X 1\right)^{2}}{n 1} \\
& \mathrm{SS} 2=\sum \mathrm{X} 2^{2}-\frac{\left(\sum X 2\right)^{2}}{n 2}
\end{aligned}
$$

Note:

$\mathrm{t}=$ Test of significance

$\overline{\mathbf{x}}_{1}=$ Mean score of experimental group

$\overline{\mathrm{x}}_{2}=$ Mean score of controlled group

$\mathrm{SS}_{1}=$ Sum square of experimental group

$\mathrm{SS}_{2}=$ Sum square of controlled group

$\mathrm{n}_{1}=$ Number of students of experimental group

$\mathrm{n}_{2}=$ Number of students of cotrolled group

(Gay, 1981:327).

\section{D.FINDINGS AND DISCUSSION}

The findings of this research deals with the rate percentage of the students' scores of pre test and post test experimental and controlled class, the frequency, mean score, standard deviation, test of significance and hypothesis testing of the faired samples. The scores of the student's experiment and control class were 
Rahmat Syam, The Effectiveness of Using Word Wall In Teaching Simple Present Tense ...

observed on the two components between pre-test and post-test. The data was presented as follow:

\section{Scoring classification of the students pre-test and post-test for Experimental Class}

The range scores were classified into seven levels based on Pusat Kurikulum Scale. The students' scores of pre-test and post-test were classified into some criteria. The criteria and percentage of the students' scores of pre-test and post-test are as follows:

\section{a. Students' Pre-test}

Table 4.1 Frequency and Percentage of Score Experimental Class in Pre-test

\begin{tabular}{|c|l|c|c|c|}
\hline No. & Classification & Scores & Frequency & $\mathbf{\%}$ \\
\hline 1 & Excellent & $96-100$ & - & - \\
\hline 2 & very good & $86-95$ & - & - \\
\hline 3 & Good & $76-85$ & - & - \\
\hline 4 & Fairly good & $66-75$ & - & - \\
\hline 5 & Fair & $56-65$ & 2 & $8.4 \%$ \\
\hline 6 & Poor & $46-55$ & 11 & $45.8 \%$ \\
\hline 7 & Very Poor & $0-45$ & 11 & $45.8 \%$ \\
\hline \multicolumn{2}{|c|}{ Total } & & $\mathbf{2 4}$ & $\mathbf{1 0 0 . 0} \%$ \\
\hline
\end{tabular}

Table 4.1 above shows the rate percentage of score of experimental class in pre-test from 24 students. Students achieved excellent, very good, good, and fairly good $0 \%$ students, two out of 24 students $(8.4 \%)$ achieved fair, 11 students $(45.8 \%)$ achieved poor, and 11 students (45.87\%) achieved very poor.

\section{b. Students' Post- test}

Table 4.2 Frequency and Percentage of Score Experimental Class in Post-test

\begin{tabular}{|c|l|c|c|c|}
\hline No. & Classification & Scores & Frequency & \multicolumn{1}{c|}{$\mathbf{0}$} \\
\hline 1 & Excellent & $96-100$ & 1 & $4.17 \%$ \\
\hline 2 & very good & $86-95$ & 3 & $12.50 \%$ \\
\hline 3 & Good & $76-85$ & 9 & $37.50 \%$ \\
\hline 4 & Fairly good & $66-75$ & 10 & $41.66 \%$ \\
\hline 5 & Fair & $56-65$ & 1 & $4.17 \%$ \\
\hline 6 & Poor & $46-55$ & 0 & $0 \%$ \\
\hline 7 & Very Poor & $0-45$ & 0 & $0 \%$ \\
\hline \multicolumn{2}{|c|}{ Total } & & $\mathbf{2 4}$ & $\mathbf{1 0 0 . 0 0 \%}$ \\
\hline
\end{tabular}


While, the rate percentage of score of experimental class in post test from 24 students as table 2 above shows that, the students achieved very poor $0 \%$ students, student achieved poor $0 \%$, and one out of 24 students achieved fair $4.17 \%$, then 10 students (41.66\%) achieved fairly good, 9 students $(37.5 \%)$ achieved good, 3 students $(12.5 \%)$ achieved very good, and 1 student $(4.17 \%)$ achieved excellent.

It means that the score and the percentages of experimental class in the post test are better than in pre-test because in the pre-test there were 11 students achieved poor and 11 students achieved very poor while in the post test are not.

\section{Scoring Classification of the Students Pre-test and Post-test for Controlled Class}

The student's scores of pre-test and post-test were classified into some criteria. The criteria and percentage of the students/ scores of pre-test and post-test are as follows:

\section{a. Students' Pre-test}

Table 4.3 Frequency and Percentage of Score Controlled Class in Pre-test

\begin{tabular}{|c|c|c|c|c|}
\hline No. & Classification & Scores & Frequency & $\%$ \\
\hline 1 & Excellent & $96-100$ & - & - \\
\hline 2 & very good & $86-95$ & - & - \\
\hline 3 & Good & $76-85$ & - & - \\
\hline 4 & Fairly good & $66-75$ & - & - \\
\hline 5 & Fair & $56-65$ & - & - \\
\hline 6 & Poor & $46-55$ & 5 & $20.83 \%$ \\
\hline 7 & Very Poor & $0-45$ & 19 & $79.17 \%$ \\
\hline \multicolumn{2}{|r|}{ Total } & & 24 & $100.00 \%$ \\
\hline
\end{tabular}

The data in table 4.3 showed that, the rate percentage of the post test score. The table above shows that the students achieved very poor 19 (79.17\%) students, then $5(20.83 \%)$ student achieved poor, and none student achieved excellent, very good, good, fairly good, even fair.

\section{b. Students' Pre-test}

Table 4.4 Frequency and Percentage of Score Controlled Class in Post-test

\begin{tabular}{|c|l|c|c|c|}
\hline No. & Classification & Scores & Frequency & \% \\
\hline 1 & Excellent & $96-100$ & - & - \\
\hline 2 & very good & $86-95$ & - & - \\
\hline 3 & Good & $76-85$ & 3 & $12.5 \%$ \\
\hline
\end{tabular}


Rahmat Syam, The Effectiveness of Using Word Wall In Teaching Simple Present Tense ...

\begin{tabular}{|c|l|c|c|r|}
\hline 4 & Fairly good & $66-75$ & 11 & $45.8 \%$ \\
\hline 5 & Fair & $56-65$ & 9 & $37.5 \%$ \\
\hline 6 & Poor & $46-55$ & 1 & $4.2 \%$ \\
\hline 7 & Very Poor & $0-45$ & - & - \\
\hline \multicolumn{2}{|c|}{ Total } & & $\mathbf{2 4}$ & $\mathbf{1 0 0 . 0 0 \%}$ \\
\hline
\end{tabular}

The data in table 4.4 showed that, the rate percentage of the pre test score (Control class). There was none of the students achieved excellent and very good, 3 $(12.5 \% \%)$ students achieved good, $11(45.8 \%)$ students achieved fairly good, then 9 $(37.5 \% \%)$ students achieved fair, one out of 24 students $(4.2 \%)$ achieved poor, and none of the students achieved very poor. In other hand that students' reading comprehension in control class was not too increase just than the experimental class.

\section{The Mean Score and Standard Deviation of Experimental Class and Controlled Class}

Table 4.5 The mean score and standard deviation of experimental class and controlled class

\begin{tabular}{|c|c|c|c|c|}
\hline \multirow{2}{*}{ Class } & \multicolumn{2}{|c|}{ Mean Score } & \multicolumn{2}{c|}{ Standard Deviation } \\
\cline { 2 - 5 } & Pre test & Post test & Pre test & Post test \\
\hline Experimental & 48.33 & 80.20 & 7.6 & 8.14 \\
\hline Controlled & 42.5 & 68.95 & 6.9 & 8.2 \\
\hline
\end{tabular}

The table indicates the mean score of experimental class in the pretest was 48.33 with the standard deviation 7.6 while the mean score in the controlled class was 42.5 with the standard deviation was 6.9. The mean score of the experimental class in the posttest was 80.20 and the standard deviation was 8.14 while the mean score of the controlled class in the posttest was 68.95 and the standard deviation was 8.2 .

In the experimental class, the mean score of the posttest was higher than the mean score of the pretest and so was the standard deviation. Thus, it could be concluded that the use of $W$ ord $W$ all is beneficial in learning Simple Present Tense.

\section{Test of Significance Testing}

The significant score between experimental and controlled class can be calculated by using t-test. The result of the t-test can be seen in table 7 as follows:

Table 4.6 Distribution the Value of t-Test and $t$-Table in post-test

\begin{tabular}{|c|c|c|}
\hline Variable & t-test value & t-table value \\
\hline Post test & 4.78 & 2.021 \\
\hline
\end{tabular}


Table 4.6 shows the result of test of significance testing. For the level of significance (p) 0, 05 and the degree of freedom $(\mathrm{df})(\mathrm{N} 1+\mathrm{N} 2)-2=(24+24)-2=$ 46 , showed that the value of the t-test was higher than t-table. The result of the test clearly showed that there was a significant difference between the students' score in the experimental and controlled class after the treatment, Word Wall. It indicated that the $W$ ord $W$ all was quite affective in improving students' ability in learning simple present tense. It means $\mathrm{H} 0$ was rejected and $\mathrm{H} 1$ was accepted because the t-test was higher than t-table (4.78.>2.021). Hence, the researcher's hypothesis was accepted.

\section{E. DISCUSSION}

\section{The Use of Simple Present Tense}

Simple preset is marked by the singular verb which is bare infinitive (verb 1) or additional infinitive (verb $1+\mathrm{s} / \mathrm{es}$ ). In control class, half of the students got wrong in choosing the right singular verb. They did not understand about the use of verb in simple present tense. They still used bare infinitive when the subject is the third person singular. In contrast, the experimental class got improvement. They also got many wrong answers in the pre-test, but it improved in the post-test.

\section{The Use of Auxiliary}

There are two auxiliaries used in simple present tense. They are "do" and "be". Auxiliary do is used for the negative and interrogative verbal sentences. Auxiliary be is used for the nominal sentences. The students got problem in differentiating when they had to use auxiliary do and when they should use auxiliary be. Experimental class and controlled class showed improvement in the post-test. But, the experiment class got higher score then control class.

\section{Time Signal}

Time signal is also used to mark whether a sentence is a simple present or not. In this term, almost the students got correct answers. They have known the time signal used in simple present. In identifying the time signal, the experimental class and the controlled class had same score. It was caused by their prior-knowledge about the time signal itself.

\section{Changing Sentence}

Changing sentence is transforming the sentence into other forms. In this term, the students should transform the positive sentence into negative sentence or interrogative sentence. It was the hardest part of the instrument because there was none student who got correct answer both in the experimental and control classes. 
Rahmat Syam, The Effectiveness of Using Word Wall In Teaching Simple Present Tense ...

The achievement was improved in the post-test. The control class, half of the students got all correct. Meanwhile, all of the students in the experimental class got all correct.

The above explanation indicates that the two groups had improvement. Both of the classes reached higher score in the post-test. The experimental class which was treated by using word wall got higher score than the control class which was not treated.

In chapter II, the researcher had presented some previous findings about using word wall in learning teaching process. Astuti (2010) had conducted a research by using word wall as media to improve speaking and the result of the researcher showed improvement. Another research was conducted by Anggriani (2013). In her research, she applied word wall strategy to improve students' vocabulary achievement. It showed positive result.

This researcher also applied word wall in teaching learning process. It was differentiated by the skill taught that was simple present tense. Same as the previous findings, this research also showed positive results that. The students got improvement in four terms of simple present taught. The researcher assumed that the use of word wall as media is really helpful in teaching learning process.

To sum up, the use of Word Wall in improving students' ability in learning simple present tense is surely beneficial. It is supported by the result of this study, which shows the students' scores were much higher after the treatment using $W$ ord W all.

\section{F. CONCLUSION}

From the discussion in the previous chapter, it can be concluded that using Word Wall can increase the students' ability in mastering simple present tense. The students' mastering simple present tense before using Word Wall is very poor. It is different from the students' mastery after using Word Wall. It was found in students post-test was higher than the pre-test, which proved that used of Word Wall in learning activity contributed to the students' more effective in teaching simple present tense. Word Wall can increase the students' mastering simple present tense. Therefore, Word Wall is helpful to activate the students' background knowledge that is very important to help students practice their mastering simple present tense.

\section{G. RECOMENDATION}

Finally, the researcher realizes that there are still many shortages in his thesis, so the researcher really expects the criticism and suggestions for the improvements. 
Thus, the researcher also hopes this thesis can be a meaningful contribution for the teacher of English as well as students and further researcher.

The teacher should make the class be interesting and enjoyable. Here, the use of Word Wall or help students see meaning in the academic material, they are studying by connecting academic subject with the context of their daily lives, contributed to motivate and stimulus the students' ability mastering simple present tense. Giving the material about making connection with situation in daily lives, so they have the background knowledge can reduce the anxiety to tell about nice experience because easy to understand.

Teacher should pay attention to the increasing of students' activities in the class. Let the students explore their potential and their ability. Finally, it is recommended that further researches could apply the word wall for the other skill or the other materials.

\section{REFERENCES}

Anggraini. D. 2013. Improving Students' Vocabulary Achievement through Word Walls Strategy. Thesis, Medan: Universitas Negeri Medan.

Arikunto, S. 2010. Prosedur Penelitian: Suatu Pendekatan Praktik. Jakarta: PT.Rineka Cipta.

Aritonang. M.M. 2013. Improving Students' Achievement on Vocabulary Through Word $W$ alls. Thesis, Medan: Universitas Negeri Medan.

Astuti. 2010. The Use of Word W all as Media to Improve Students' Speaking Speaking Ability, an Action Research at the First Year Students of SMPN 1 Temanggung in the Academic Year of 2009/2010. Thesis, Semarang: Universitas Negeri Semarang.

Azar, B. 1989. Understanding and Using English Grammar Second Edition. United States: Prentice Hall Regents.

Brummitt, J. 2012. 10 Great Word Wall Strategies for Classrooms. Retrieved on 20 July 2014. From: http://www.k12reader.com/10-great-word-wall-strategies-forclassrooms.

Cronsberry, J. 2004. Word Walls: A support for literacy in secondary school classroom. Retrieved on December $14^{\text {th }} 2014$ from http://curriculum.org/storage/ 258/1334340769/World Walls A Support for Literacy in Secondary Sch ool Classrooms.pdf

Farris, P.J., Fuhler, C.J., \& Walther, M.P. 2004. Teaching Reading: A Balanced Approach for Today's Classrooms. New York: McGraw-Hill.

Gay,L.R. 1981. Educational Research: Competencies for Analysis and Application. Second edition. Columbus, Ohio: Cambridge University Press. 
Rahmat Syam, The Effectiveness of Using Word Wall In Teaching Simple Present Tense ...

Indrayana. I.D.G.A. 2014. The Use of Word Wall Game to Teach Writing Skill of The Eighth Grade Students of SMPN 2 Blabbatuh in Academic Year 2013/2014. Thesis, Bali: Universitas Mahasaraswati.

Jannah, N. 2014. The Effectiveness of Narrative Text in Enhancing the Second Year Students' Ability in Mastering Simple Past Tense at SMP Al-Furqan Ereng-Ereng. Thesis, Makassar: UIN Alauddin Makassar.

Jasmine, J., \& Schiesl, P. 2009. The Effects of Word Walls and Word Wall Activities on the Reading Fluency of First Grade Students. Reading Horizons. Volume 49, No. 4, retrieved from: http://scholarworks.wmich.edu/cgi/viewcontent.cgi?article= $\underline{1065 \& \text { context }=\text { reading horizons }}$

Kirn, E., \& Darcy, J. 2002. Interaction 1 Grammar 4th Edition. New York: McGrawHill.

Murphy. R. 1998. English Grammar in Use The Second Edition. Cambridge University Press.

Putri, Y.F., 2013. Students' Errors in Using Simple Present Tense in Writing Descriptive Texts. Thesis, Malang: Universitas Negeri Malang. Retrieved on December $14^{\text {th }} 2014$ from http://jurnal-online.um.ac.id/data/artikel/artikel3A1753E6DE407244 D75D923DEC146005.pdf

Sudjana. 2008. Metode Statistika. Bandung. 